Progress. Agric. 18(2) : 49-55, 2007

ISSN 1017-8139

\title{
COMPARATIVE GENETIC EFFECT OF DWARFING GENES ON YIELD AND YIELD CONTRIBUTING TRAITS IN BREAD WHEAT (Triticum aestivum L.)
}

\author{
M. A. Jahan, M. S. Hossain'1, M. Khalekuzzaman'1 and M. M. Hassan ${ }^{2}$ \\ Department of Genetics, Shah Jalal University of Science and Technology \\ Sylhet-3114, Bangladesh
}

\begin{abstract}
Norin 10 based dwarfing genes $\left(R h t_{1}\right.$ and $\left.R h t_{2}\right)$ have been widely exploited for increasing the grain yield in bread wheat (Triticum aestivum L.) by improving partitioning of assimilates to grain. Eight semi-dwarf wheat genotypes having either $R h t_{1}$ or $R h t_{2}$ dwarfing genes were compared with a tall control named, Kheri $(r h t)$ having no dwarfing genes were evaluated at Rajshahi University, Bangladesh for yield and yield contributing traits. Significant differences in grain yield and yield components were observed in genotypes under study showing the effects of dwarfing genes. Genotype Seri $82\left(R h t_{1}\right)$ and Kanchan $\left(R h t_{2}\right)$ had medium plant height of 75.73 and $72.22 \mathrm{~cm}$ respectively, highest number of tillers/plant (7.33 and 7.67), highest number of spikes/plant (6.33 and 6.67) resulted the highest grain yield per plant. Because the dwarfing genes not only provide lodging tolerance but also perhaps pleiotropically affected high yield by allowing more tillers to survive. Number of tillers/plant and number of spikes/plant showed very strong positive correlation with grain yield per plant in all the genotypes. Kheri (rht) with highest plant height $(95.17 \mathrm{~cm})$ reduced number of tillers/plant (4.00) and spikes/plant (3.67) had the lowest grain yield per plant (3.85g). Aghrani possessed significantly the highest number of grains/spike with medium grain yield/plant (5.94g). The degree of relationship varied from genotype to genotype.
\end{abstract}

Key Words : Grain yield, Semi-dwarfing genes, Triticum aestivum L., Wheat

\section{INTRODUCTION}

The Japanese wheat variety 'Norin 10' was introduced in 1946 and imported into USA in 1948 as a source of dwarfing genes and it was then used to develop Norin 10/Brevor 14 by Vogel et al. (1956) and was subsequently used by Borlaug (1968) and many others as a primary source of $R h t_{1}$ and $R h t_{2}$ genes. The genetic system of Norin 10 dwarfism is now understood to consist of two partially recessive independent genes, $R h t_{1}$ and $R h t_{2}$, which act additively. The semi-dwarfing or reduced height genes $R h t_{1}$, (Rht-B1b) and $R h t_{2}$ (RhtD1b) have been extensively used for developing high yielding varieties with reduced

1Department of Genetic Engineering and Biotechnology, University of Rajshahi, Rajshahi-6205, Bangladesh

2 Department of Botany, University of Rajshahi, Rajshahi-6205, Bangladesh 
plant height and lodging resistance (Gale and Youssefian, 1985; Rebetzke and Richards, 2000). The dwarfing genes not only provide lodging tolerance but also perhaps pleiotropically influence high yield by allowing more tillers to survive and thus increase biomass. The semi-dwarting genes $\mathrm{Rht}_{1}$ and $\mathrm{Rht}_{2}$ have been known to modify the plant ideotype by changing its cell size and number; root weight, coleoptile length, leaf size, harvest index, grain yield and yield components, protein content, disease reaction and gibberallic acid (GA) insensitivity (Gale and Youssefian, 1985; Loskutova, 1998). Apart from this shortness due to dwarfing genes, other desirable features of the dwarfs are increased tillering and high grain number/spike (Borlaug, 1968; Gale, 1978).

N.E. Borlaug and his co-workers have developed a good number of genetically reduced short-statured and lodging resistant high yielding wheat varieties, namely, Sonora 64, Lerma Rojo 64, Maxipak 65, Inia 66 etc (Borlaug, 1988). Lodging can cause yield losses of $12-66 \%$ depending upon the degree of lodging (Vaidya and Ram, 1986). Lodging at the beginning of the grain filling period has been shown to reduce grain yield by $50-80 \%$ (Easson et al., 1993).

The aim of this work was to analyse the comparative action of dwarfing genes ( $R h t_{1}$ and $\left.R h t_{2}\right)$ for improving grain yield and Kheri $(r h t)$ was used as a control in this case.

\section{MATERIALS AND METHODS}

Eight semi-dwarf wheat (Triticum aestivum) genotypes namely Inia 66, Sonalika, Kalyansona and Seri 82 having $R h t_{1}$ dwarfing gene, Kanchan, Aghrani, Sonora 64 and Pavon 76 with $R h t_{2}$ dwarfing gene and the genotype Kheri $(r h t)$ without dwarfing genes were studied in this experiment. Seeds were collected from Regional Wheat Research Centre (RWRC), BARI, Rajshahi,Bangladesh and were seeded at an experimental farm of Genetics and Breeding Department, Rajshahi University in the Rabi season of 2004-05. The genotypes were grown in single row plot according to randomized completely block design (RCBD) with three replication for this agronomic study. Recommended agronomic practices were followed as and when necessary and the data of all the plants were recorded. Ten plants at random from each replication were selected for this agronomic studies. The following five characters were studied.

1. Plant height : The length of the main tillers at maturity were measured in $\mathrm{cm}$ from the ground level to the tip of its terminal spikelet excluding awns and the average was taken.

2. Total number of tillers/plant : Total number of tillers/plant were measured at maturity stage.

3. Total number of spikes/plant : Total number of spike bearing tillers were counted from the sample plant and were averaged per plant.

4. Total number of grains/spike : Total number of grains were counted from main spike of each sample plant and then average was taken. 
5. Grain yield/plant : Total grains of the sample plants was weighted in gram and the average was taken.

Data were statistically analysed and to distinguish the significant differences between two different means, Least Significant Differences (LSD) were estimated. Mean square of analysis of variances were worked out to test the significance (Table 2). The simple correlation coefficients were calculated from varietal means and the averages of each group $\left(R h t_{1}, R h t_{2}\right.$ and $\left.r h t\right)$ and are shown in Table 3.

\section{RESULTS AND DISCUSSION}

Mean square of analysis of variance (Table 2) indicated that almost all the traits were influenced $(\mathrm{p}<0.01)$ by the dwarfing genes suggesting significant genetical differences among the three groups of genotypes viz., rht, $R h t_{1}$ and $R h t_{2}$ having different plant heights. The control genotype Kheri with rht genes, has the highest plant height of 95.17 $\mathrm{cm}$ compared to genotypes having $R h t_{1}$ and $R h t_{2}$ genes and had significantly lowest tillers/plant, spikes/plant, and number of grains/spikes, which resulted in ultimate lower grain yield/plant was 3.85g (Table 1).

Table 1. Mean differences in five agronomic traits of nine wheat genotyes

\begin{tabular}{l|ccc|c|c|c}
\hline Genotypes & $\begin{array}{c}\text { Genotypic } \\
\text { group }\end{array}$ & $\begin{array}{c}\text { Plant } \\
\text { height }(\mathrm{cm})\end{array}$ & $\begin{array}{c}\text { Total no. of } \\
\text { tillers/plant }\end{array}$ & $\begin{array}{c}\text { Total no. of } \\
\text { spikes/plant }\end{array}$ & $\begin{array}{c}\text { Total no. of } \\
\text { grains/spike }\end{array}$ & $\begin{array}{c}\text { Grain } \\
\text { yield/plant (g) }\end{array}$ \\
\hline Inia 66 & $R h t_{1}$ & 73.17 & 5.67 & 4.33 & 34.00 & 4.65 \\
Sonalika & $R h t_{1}$ & 73.13 & 5.67 & 4.67 & 36.33 & 4.94 \\
Kalyansona & $R h t_{1}$ & 64.82 & 6.67 & 5.67 & 39.00 & 6.10 \\
Seri 82 & $R h t_{1}$ & 75.73 & 7.33 & 6.33 & 42.67 & 7.66 \\
Kanchan & $R h t_{2}$ & 72.22 & 7.67 & 6.67 & 40.67 & 7.15 \\
Aghrani & $R h t_{2}$ & 74.26 & 6.00 & 5.33 & 51.34 & 5.94 \\
Sonora 64 & $R h t_{2}$ & 67.98 & 5.33 & 4.67 & 38.00 & 4.33 \\
Pavon 76 & $R h t_{2}$ & 76.86 & 6.33 & 5.33 & 45.67 & 4.92 \\
Kheri & $r h t$ & 95.17 & 4.00 & 3.67 & 30.33 & 3.85 \\
\hline LSD(5\%) & \multicolumn{7}{c}{6.64} & 0.945 & 0.874 & 4.788 & 1.005 \\
\hline LSD(1\%) & 9.14 & 1.302 & 1.204 & 6.595 & 1.384 \\
\hline
\end{tabular}

LSD indicates the least significant differences at $5 \%$ and $1 \%$ level, respectively

The variety Seri 82 having $R h t_{1}$ dwarfing genes in them has the medium plant height of $75.73 \mathrm{~cm}$ had significantly higher number of tillers/plant (7.33), highest number spikes/plant (6.33) which leads to highest grain yield per plant of 7.66 g. Similarly, variety Kanchan having $R h t_{2}$ dwarfing genes have the plant height of $72.22 \mathrm{~cm}$ had significantly highest number of tillers/plant (7.67) and spikes/plant (6.67) which resulted the higher grain yield per plant $(7.15 \mathrm{~g})$. This result is similar to that of Hoogendoorn et al. (1988) were able to show that yield increased by at least $15 \%$ when $R h t_{1}, R h t_{2}$ or $R h t_{1}+$ 
$R h t_{2}$ carrying lines were compared to tall cultivar and only $R h t_{1}$ and $R h t_{2}$ significantly raise grain yield. This may not be true in every case as Pinthus and Levy (1983) reported that the presence of $R h t_{1}$ and $R h t_{2}$ genes caused no increase in grains/spike and the tall genotypes had the highest mean number of grains/spike. However, short statured wheat varieties are considered as breeding prerequisite in many of the wheat growing countries of the world (Schillinger et al., 1998).

Table 2. Mean square of analysis of variance of five agronomic traits of nine wheat genotyes

\begin{tabular}{l|c|c|c|c|c|c}
\hline \multicolumn{1}{c}{$\begin{array}{c}\text { Source of } \\
\text { variation }\end{array}$} & d.f. & \multicolumn{5}{|c}{ ms } \\
\cline { 3 - 7 } & & Plant height & $\begin{array}{c}\text { Total no. of } \\
\text { tillers/plant }\end{array}$ & $\begin{array}{c}\text { Total no. of } \\
\text { spikes/plant }\end{array}$ & $\begin{array}{c}\text { Total no. of } \\
\text { grains/spike }\end{array}$ & $\begin{array}{c}\text { Grain } \\
\text { yield/plant }\end{array}$ \\
\hline Replication (R) & 2 & 16.190 & 0.456 & 0.386 & 12.574 & 0.513 \\
Genotype (G) & 8 & $72.317^{* *}$ & $1.217^{* *}$ & $0.919^{*}$ & $39.483^{* *}$ & $1.675^{* *}$ \\
Within $R h t_{1}$ & 3 & 22.598 & 0.662 & $0.842^{*}$ & 13.866 & $1.868^{* *}$ \\
Within Rht $_{2}$ & 3 & 14.060 & $0.968^{*}$ & 0.705 & $34.576^{*}$ & $1.531^{*}$ \\
Between & 2 & $234.280^{* * *}$ & $2.423^{* *}$ & $1.356^{*}$ & $85.269^{* * *}$ & $1.602^{*}$ \\
Error (GXR) & 16 & 14.700 & 0.298 & 0.255 & 7.651 & 0.337 \\
\hline
\end{tabular}

${ }^{*},{ }^{* *},{ }^{* *}$ denote significant at $5 \%, 1 \%$ and $0.1 \%$ levels, respectively

The genotype Kalyansona having $R h t_{1}$ dwarfing genes in them was the shortest (64.82 $\mathrm{cm})$ among all in the plant heights and had the higher grain yield/plant $(6.10 \mathrm{~g})$. Similarly, Sonora 64 having $R h t_{2}$ dwarfing genes in them was shorter $(67.98 \mathrm{~cm})$ in height had the lowest grain yield/plant $(4.33 \mathrm{~g})$ except Kheri where the grain yield per plant was $3.85 \mathrm{~g}$. These results suggested that increasing in plant height up to certain extent may produce higher grain yield and support the idea of "tall dwarf" plant height model suggested by Gale and Law (1977). Busch and Rauch (1993) in their study on agronomic performance of tall versus short semi-dwarf lines did not found sufficient evidence to support the application of the "tall-dwarf" model in their hard red spring wheat germplasm.

Data from the experiments were consisted with a model for height/yield relationships in which the pleiotropic effects of the Rht alleles on yield can be inferred from their primary function, insensitivity to gibberellin limits stem extension growth, decreasing assimilate demand for this organ and diverting it to the developing ear. The net balance between the resulting increase in harvest index and the curvilinear relationship observed between plant height and total shoot yield results in optimum grain yields at intermediate plant heights (Flintham et al., 1997). The optimum plant height for yield improvement in different genetic backgrounds was achieved by different $R h t$ alleles according to the background varietal height, such that intrinsically taller genotypes required more potent $R h t$ alleles to achieve maximum potential grain yield. 
Aghrani and Pavon 76 having $R h t_{2}$ dwarfing gene in them had significantly highest number of grains/spike, which was 51.34 and 45.67, respectively but had minimum grain yield/plant $5.94 \mathrm{~g}$ and $4.92 \mathrm{~g}$ respectively than other genotypes because their grains were not so heavy as compared to other genotypes of $R h t_{1}$ and $R h t_{2}$ group or rht group. The rest two genotypes, Inia 66 and Sonalika having statistically similar plant height were not so important to all for most of the traits. These results agreed with Gale and Youssefian, (1985), Beharev et al. (1998). Genotype Seri 82 and Kanchan had the highest grain yield per plant respectively $7.66 \mathrm{~g}$ and $7.15 \mathrm{~g}$ which was mainly contributed by higher number of spikes/plant. An increased number of spikes per unit area often results in high grain yield (Villareal et al., 1992). Grain yield of wheat has been continuously increasing by genetic improvements and increased agronomic inputs. Semi-dwarf spring cultivars having lodging resistance also do not require vernalization (Busch and Rauch, 1993).

The simple correlation coefficients among the five characters were calculated from varietal means and from mean performance of groups and are given in Table 3. Number of tillers/plant and number of productive spikes/plant showed highly significant positive correlations with grain yield/plant in all the genotypes. Seri 82, Kanchan and Kalyansona had the higher number of tillers/plant and spikes/plant resulted in ultimate higher yield. Kheri had the lowest number of tillers and or spikes/plant produced lowest yield. Correlation coefficients among the mean performance of three groups $\left(R h t_{1}, R h t_{2} \&\right.$ $r h t)$ indicated that negative correlation existed between plant height and grain yield/plant, which indicated the visible effect of dwarfing genes on yield. Sikka and Maini (1962) reported significant positive correlation between yield per plant and number of ear bearing tillers and kernel weight. The yield is a polygenic phenomenon and depends on its associated components. Spikes per unit area is one of the important yield components and is considered as the pleiotropic effect of Norin 10 genes (Kertesz et al., 1991). Highly significant positive correlation between the number of tillers per plant and number of spikes/plant. The Norin 10 dwarfing genes, $R h t_{1}(R h t-B 1 b)$ and $R h t_{2}$ (Rht$\mathrm{D} 1 b)$, reduced plant height and increase grain yield by altering the proportion of dry matter allocated to the grain (harvest index), and by reducing plant lodging, especially with increasing environmental yield potential (Rebetzke and Richards, 1999).

Table 3. Correlation coefficients (r) among five characters in nine wheat genotypes (upper level) and in the average of three groups (lower level)

\begin{tabular}{l|c|c|c|c}
\hline \multicolumn{1}{c|}{ Characters } & $\begin{array}{c}\text { Total no. of } \\
\text { tillers/plant }\end{array}$ & $\begin{array}{c}\text { Total no. of } \\
\text { spikes/plant }\end{array}$ & $\begin{array}{c}\text { Total no. of } \\
\text { grains/spike }\end{array}$ & $\begin{array}{c}\text { Grain } \\
\text { yield/plant }(\mathrm{g})\end{array}$ \\
\hline Plant height $(\mathrm{cm})$ & -0.589 & -0.498 & 0.353 & -0.374 \\
& $-0.999^{*}$ & -0.986 & -0.882 & $-0.997^{*}$ \\
Total no. of & & $0.970^{* * *}$ & 0.539 & $0.909^{* * *}$ \\
tillers/plant & & 0.992 & 0.900 & 0.993 \\
Total no. of & & & 0.596 & $0.938^{* * *}$ \\
spikes/plant & & & 0.948 & 0.971 \\
Total no. of & & & 0.514 \\
grains/spike & & & 0.844 \\
\hline
\end{tabular}

$*, * * *$ denotes significant at the $5 \%$ and $1 \%$ probability levels, respectively 
The 'Norin 10' based semi-dwarf wheats have been extensively used in the development of high yielding cultivars at global level. The results showed that number of tillers per plant possessed very strong positive correlation with grain yield per plant, while the extent of correlation between plant height and grain yield varied among the genotypes. The maximum grain yield was produced by the genotypes Seri 82 and Kanchan, which was medium in plant height. The presence of dwarfing genes prevent excessive plant height, while minor gene variation for height could be exploited to select for taller, high yielding semidwarfs. Plant height being more heritable than yield, selection for taller plants in a given semi-dwarf population may serve as a useful selection criteria for higher grain yield.

\section{REFERENCES}

Beharev, A., Cahaner, A. and Pinthus, M. J. 1998. Genetic correlations between culm length, grain yield and seedling elongation within tall $\left(r h t_{1}\right)$ and semi-dwarf $\left(R h t_{1}\right)$ spring wheat (Triticum aestivum L.). Europ. J. Agron., 9:35-40.

Borlaug, N. E. 1968. Wheat breeding and its impact on world food supply. In: Proc. 3rd Inter. Wheat Symp. (Australian Aca. Sci. pp. 1-36

Borlaug, N. E. 1988. Challenges for global food and fiber production. J. Royal Swedish Acad. Agric. Forestry (Suppl.), 21 : 15-55.

Busch, R. H. and Rauch, T. L. 1993. Agronomic performance of tall versus short semi-dwarf lines of spring wheat. Crop Sci., 33 : 941-943.

Easson, D. L., White, E. M. and Pickles, S. J. 1993. The effects of weather, seed rate and cultivars on lodging and yield in winter wheat. J. Agricl. Sci. Cambridge. 121 : 145-156.

Flinthum, J. E., Borner, A., Worland, A. J. and Gale, M. D. 1997. Optimizing wheat grain yield: effects of Rht (gibberellin-insensitive) dwarfing genes. J. Agric. Sci., 128 : 11-25. Cambridge University Press.

Gale, M. D. 1978. The effects of Norion-10 dwarfing genes on yield. Proc. 5th Int. Wheat Genetics Symp. (New Delhi) 978-987 pp.

Gale, M. D. and Law, C. N. 1977. The identification and exploitation of Norin-10 semi-dwarfing genes. In: Plant Breeding Institute Cambridge Ann. Rep. 1976. UK, pp. 21-35.

Gale, M. D. and Youssefian, S. 1985. Dwarfing genes of wheat. In : (Russell G. E. Ed.),Progress in Plant Breeding I. Butterworths. London, UK. pp. 1-35.

Hoogendoorn, J., Pfeiffer, W. H., Rajaram, S. and Gale, M. D. 1988. Adaptive aspects of dwarfing genes in CIMMYT germplasm. In T. E. Miller and R. M. D. Koebner, eds. Proceedings of the $7^{\text {th }}$ International Wheat Genetics Syposium. pp. 1093-1100. Cambridge, UK.

Kertesz, Z., Flintham, J. E. and Gale, M. D. 1991. Effects of Rht dwarfing genes on wheat grain yield and its components under Eastern European conditions. Cereal Res. Comm., 19 : 297- 304.

Loskutova, N. P. 1998. The influence of $\mathrm{Rht}_{1-5}$, Rht $\mathrm{R}_{8-9}$ and $\mathrm{Rht}_{13}$ genes on morphological characters and yield productivity of wheat. In: (Slinkard, A. E., ed), Proc. 9th Int. Wheat Genet. Symp., University Extension Press. University Saskatchewan. Saskatoon, pp. 283-284.

Pinthus, M. J. and Levy, A. A. 1983. The relationship between the $\mathrm{Rht}_{1}$ and $\mathrm{Rht}_{2} \mathrm{dwarfing}_{\text {genes and }}$ grain weight in Triticum aestivum L. spring wheat. Theor. Appl. Genet., 66 : 153-157. 
Rebetzke, G. J. and Richards, R. A. 2000. Gibberellic acid-sensitive dwarfing genes reduce plant height to increase kernel number and grain yield of wheat. Aust. J. Agric. Res., 51 : 235-245.

Rebetzke, G. J. and Richards, R. A. 1999. Genetic improvement of early vigor in wheat. Aust. J. Agric. Res., 50 : 291-301.

Schillinger, W. F., Donaldson, E., Allan, R. E. and Jones, S. S. 1998. Winter wheat seedling emergence from deep sowing depths. Agron. J., 90 : 582-586.

Sikka, S. M. and Maini, N. S. 1962. Correlation studies in some Punjab Wheat's. Indian J. Genet. Pl. Breed., 22(3) : 181-186.

Vaidya, S. M. and M. Ram. 1986. A single lodging index for barley. RACHIS. 5(1) : 14.

Villareal, R. L., Rajaram, S. and Del Toro, E. 1992. Yield and agronomic traits of Norin-10 derived spring wheats adapted to North Western Mexico. J. Agron. Crop Sci., 168 : 289-297.

Vogel, O. A., Craddock, Jr., Muir, C. E., Everson, E. H. and Rohde, C. R. 1956. Semidwarf growth habit in winter wheat improvement for the Pacific North-west. Agron. J., 48 : 76-78. 